\title{
Research on the Reform of Ideological and Political Education in Colleges against the Background of Diversification
}

\author{
ZHANG Yanhui \\ College of Marxism, Baicheng Normal University, Baicheng 137000, China \\ email: huizipin@126.com
}

Keywords: Cultural Diversity, Colleges, Reform of Ideological and Political Education

\begin{abstract}
With the arrival of economic globalization, cultural pluralism is the product derived from it. Cultural diversity is reflected in the cultural exchange and cultural collision. At the same time, cultural diversity also affects all aspects of society.The author analyzes and compares the ideological and political teaching reform in colleges and universities under the background of cultural diversity through the influence of cultural diversity on various levels of colleges and universities, hoping to pass through the tide of cultural diversity which faces opportunities and challenges. This paper points out a clear way for the reform of ideological and political teaching in colleges and universities. Through analysis and comparison, the author puts forward the direction and road of ideological and political reform in colleges and universities under the background of cultural diversity.
\end{abstract}

\section{Introduction}

The influence of cultural diversity on contemporary college students is of great significance and the breath of cultural diversity affects the world outlook, outlook on life and values of college students. Nowadays, the ideological and political teaching in colleges and universities is not suitable for cultural diversity. The application of the old ideological and political teaching methods will inevitably affect the realization of the goal of talent training in colleges and universities. Therefore, the reform of ideological and political teaching has become inevitable. In real life, what culture provides to people is no longer simple color and fixed idea, but characterized by full of variety, which is the coexistence of native culture, foreign culture and mixed culture produced by the fusion of many cultures. Cultures in different regions, countries, and social systems of the world merge, absorb and coexist in the same environment[1]. This is the impact of cultural diversity on the whole world, specifically to the impact of colleges and universities, the author will analyze the impact of various levels and show the impact of cultural diversity on the ideological and political institutions and the corresponding teaching reform policies.

\section{The Influence of Cultural Diversity Conflict on College Students}

Weak Political Consciousness and Crisis of Belief. Specifically, in the political beliefs of college students, there are some western values that have a particularly profound impact on college students, and some people cannot afford the temptation and are willing to believe in western values, who have lost the mainstream ideology that has guided us forward, that has even led to the emergence of radical ideas against Marxism-Leninism, against Mao Zedong thought, and against Deng Xiaoping theory. Most of these people have been influenced by western values and have lost themselves because they can not distinguish between right and wrong. This kind of lost ego is mainly reflected in the students' distrust and doubt of the ruling party.

The Gradual Degradation of National Consciousness and Patriotic Concept. With the deepening of economic globalization in our country, the subjective right of national culture, national culture and the spirit of our country have had a great impact and impact. At the same time, the concept of national sovereignty and patriotism in the hearts of young people has been gradually diluted. For example, in the wave of economic globalization, the western ideas of "all damage, all prosperity", "the disappearance of national boundaries," and "human rights above sovereignty" have 
seriously confused the thinking of college students. Some college students even think that with the promotion of economic globalization, countries and countries will no longer exist, the world will be a large global village. The large space of cultural diversity can enable college students to learn a lot of useful things, such as exposure to advanced foreign culture and raise their ideological and moral level. However, negative culture also makes students lose the ability to distinguish, that is easy to misunderstand and doubt our own country, nation and national belief, and even some college students may lose faith[2]. The commercial culture of the west also greatly affects the values and moral behavior of college students, which makes them lose confidence in the cultural and political aspects of their own nation and kill their will.

The Way of Cultural Communication Challenges the Initiative of Ideological and Political Education. The pluralistic culture has been spreading and developing through various ways, which has injected fresh blood into the ideological education of college students, provided new channels of contact, and also provided new means and weapons, at the same time, the formation of college students thoughts is also influenced by these cultures to varying degrees. There are many forms of cultural diversification. Nowadays, college students mostly rely on the network to acquire knowledge, but virtual network is not a simple virtual space, it is the result of the development of the real society to virtual space. The network culture is not uniform, and many cultures are mixed up to challenge the initiative of ideological and political education in colleges and universities.

Cultural Pluralism has Impacted the Construction of the Main Channel of Ideological and Political Teaching in Colleges and Universities. In recent years, with the continuous development of information technology, the cultural communication of electronic and network mode has become a new carrier of ideological and political teaching. The traditional ideological and political education is challenged by cultural diversity, and the university students are challenged by the cultural diversity as well as by the complexity of the network. The influence of foreign culture on our country is expanding rapidly. How to control and supervise the dissemination content and information channel of these information can effectively avoid the bad influence of foreign culture on ideological and political education in colleges and universities of our country.

The Impact of Cultural Diversity Expands the Space of Ideological and Political Teaching in Colleges and Universities. The ideological and political teaching in colleges and universities is very open, and cultural diversity brings about the culture of different countries and regions in the world, which makes the diverse culture in the same environment. On the one hand, cultural diversity can eliminate cultural hegemonism and cultural centralism, on the other hand, it can make regional culture exchange and merge with different cultures in the world. Cultural diversity not only broadens the vision of college students, but also increases their moral understanding and political sensitivity.

\section{The Influence of Cultural Diversity on Teachers}

Cultural pluralism weakens the isolation mechanism in Chinese traditional culture, absorbs the outstanding achievements of other disciplines, and enriches the teaching contents of ideological and political courses in colleges and universities. The invasion of foreign culture has aggravated the sense of crisis and urgency of college ideological and political teachers to inherit national culture, and enhanced the degree of their attaching importance to inheriting excellent culture and patriotism emotion. In order to strengthen the infiltration and study of teachers traditional culture, we should turn this learning activity into a long-term and stable learning mechanism, not just a few showy performances. Each teacher should form the habit, let the outstanding cultural thought deeply into the hearts of the people, bone marrow and deep soul[3].

Under the background of cultural diversity, ideological and political teachers in colleges and universities also come into contact with and understand a large number of advanced teaching methods and teaching concepts in foreign countries, which urges them to absorb the essence of teaching mode and teaching thinking, to carry out continuous reform and to keep pace with the times. By adopting flexible and diverse educational methods, students can form correct world outlook, outlook on life and values, thus solving the deep-seated ideological problems of students. 


\section{The Necessity of Ideological and Political Reform in Colleges and Universities}

Over the past 30 years, with the deepening of China reform and opening up, more and more foreign cultures have begun to invade our country and have an important influence on the outlook on life and the world outlook of people. Especially in recent years, with the continuous development of Internet technology, the speed of foreign culture invasion is more rapid, especially young people, who are especially influenced by the influence of foreign culture, this kind of influence has caused the impact to the mainstream culture to a great extent. Colleges and universities are the cradle for young people to grow up and become talented, and the best time for young people to mature their minds. In this period, how can college students be able to distinguish, choose, and select the essence of their minds, and can root in the traditional culture and not be attracted and confused by the beautiful coat of foreign culture when they are faced with various cultural choices, that is an important proposition that all college teachers need to think carefully about in the course of ideological and political teaching.

College students gradually lose the theory of traditional ideological and political teaching, and appears the behavior of serious foreign culture tendency, and the influence of ideological and political teaching becomes smaller. Therefore, the ideological and political reform in colleges and universities becomes inevitable. Through the ideological and political reform in colleges and universities, students can be helped to firm their ideals and beliefs, and then to establish a correct outlook on life, world outlook and values. Nowadays, the effect of ideological and political curriculum construction in colleges and universities is far less effective than in the past, especially because of the influence of cultural diversity. Many college students have acquired new culture through the Internet, and gradually formed a high degree of recognition of foreign cultures. The negation of the culture in our country makes the ideological and political teaching in colleges and universities fail to show its function, which is the main reason for the ideological and political reform[4].

\section{Concrete Measures of Ideological and Political Reform in Colleges and Universities}

Take the Traditional Cultural Values as the Foothold. The reform of ideological and political education in colleges and universities must have a clear foothold, that is, based on the traditional culture of the Chinese nation, which is the foundation of all reforms, and no one can waver. So first of all, in teaching, to tell young people, what is traditional culture. China has five thousand years of civilization history, in the long process of development, has formed the traditional cultural view with the Confucian culture as the core, simply said that is five words: benevolence, righteousness, ceremony, wisdom, faith.

"Righteousness" means morality, that is a kind of understanding, pure inner integrity in dealing with the relationship between people. When it comes to the word "courtesy", one will immediately think of the word "state of propriety". Chinese people have always attached the most importance to "courtesy" in the communication between people. When it comes to "wisdom," there is an old Chinese saying, "knowing people is wise, knowing themselves", that is the open-minded attitude of intelligent people in dealing with relationships. "Faith" means honesty, which is a fundamental principle of communication between people since ancient times. Only treat others with sincerity, person with faith, can win for oneself the respect of others and society." Benevolence, righteousness, ceremony, wisdom, faith" , in brief , as the five - word truth of the traditional culture , their great influence and widespread circulation cannot be compared by another kind of culture in our country.

Accept the Advanced Western Cultural Ideas. During the period of May 4th Movement, the western culture poured into our country like the sea water during the high tide. At that time, the debate between the two cultures was launched with Peking University as the center. President Cai Yuanpei, with a grand mind, put forward the idea of "all-embracing", so that the two kinds of incompatible culture on the stage of Peking University launched a fierce debate. Looking back today, President Cai Yuanpei dared to do so, not only need the mind and spirit, but also need a strong confidence in traditional culture, if there is no confidence, who dare to let foreign culture 
raging in the platform of Peking University. Today, we are facing the impact of Western culture and foreign culture, which is even more fierce than it was a hundred years ago. Well, the vast number of ideological and political teachers in colleges and universities do not have to avoid foreign culture from the rostrum. We have to speak out and bravely bring western culture to the classroom to talk about it, and let the students identify which cultures are excellent and fit into our traditional culture for our own use, and which are the dross of culture, which are not worth mentioning. We understand this culture in order to better understand its nature[5]. As long as our teachers are rooted in the rock of traditional culture, and then guide students to establish a cultural view of "sublation", students will be able to correctly face Western culture and know how to accept and reject.

Create Inclusive Teaching Model. No one will progress if he is self complacent; if any culture is left behind, it will lead to a backward and beaten situation. In the process of the traditional culture of our country development, it has been strengthened and developed through the process of fusion with the culture of foreign nations. Therefore, for the coexistence of multiculturalism and the invasion of foreign cultures, we must not be surprised by the invasion of foreign cultures. In the classroom, the teachers of colleges and universities should teach with an inclusive teaching method, neither avoiding the foreign culture nor demonized the western culture. All cultures can be passed down in the course of historical development, all have their own valuable and desirable, of course, there are inevitably its own weaknesses and drawbacks. It is precisely because colleges and universities are faced with teaching objects that are already relatively mature college students, therefore, teachers should not inculcate their own ideas hard on students. This stereotyped teaching method may also have some effect on primary school students. But for people in their 20s, it is not only inappropriate, but often counterproductive. Therefore, ideological and political teachers must have a certain mind and self-confidence. Just like the former principal of Cai Yuanpei, we must firmly believe that our traditional culture is the best, and that foreign culture, no matter how good, cannot replace our own traditional culture. For the dross of foreign culture, we must have the power to abandon it.

Perfect the Pre-existing Contents of Ideological and Political Education in Colleges and Universities. Any teaching development, teachers should be based on textbooks with syllabus as the criteria, it can be said that the content of teaching is a bridge between teachers and students and is the link to make teaching smooth, effective development. But in the past, the content of ideological and political education in colleges and universities is not flexible enough, there are a lot of theoretical exposition in teaching, the content is partial to the red tape, the pertinence is not strong. In addition, for the new theory of multiculturalism, the new knowledge points can not be supplemented in time, which also brings some difficulties to teachers teaching. Faced with this situation, the majority of university teachers need to make long-term efforts to improve the existing ideological and political teaching content, appropriately add some current political content, reschedule the structure of teaching materials, remove some tedious knowledge points, fill in some theories and ideas with the times, and increase the discussion between students and teachers. Expect to achieve the success of teaching reform in colleges and universities in the common exchange of teachers[6].

Rationally Adjust the Ideological and Political Teaching Methods in Colleges and Universities. Good theory can be carried out smoothly and good content wants to get good dissemination, all need good method as support and lead. In the past, the ideological and political teaching in colleges and universities emphasized too much on the instillation of theory, but neglected to communicate and discuss with students who are the thoughtful individual. In the context of multiculturalism, it will never work if we follow the same old path. Therefore, in teaching, we must pay attention to the reform of teaching methods, grasp the relationship between theory and reality, can not talk about theory, let alone empty theory, let the theory be based on the foundation of reality, and let the students feel the timeliness of the theory. In addition, in teaching, we must always pay attention to make a positive, positive guidance to the students, must not show students negative, negative teaching materials, so that students thoughts cast a shadow. 


\section{Conclusion}

Under the background of cultural diversity, the reform of ideological and political teaching in colleges and universities is a long-term and continuous subject, which needs to be adjusted constantly according to the situation of the times to adapt to the development of the requirements of the times. Colleges and universities should carry out comprehensive reform on ideological and political teaching from the aspects of strengthening the construction of ideological and political education team, reforming the contents of ideological and political education and innovating the ideological and political teaching, in combination with the actual problems in their own ideological and political teaching. And then guide college students to deal with the phenomenon of cultural pluralism correctly, set up the correct world outlook, outlook on life and values, strengthen the Marxist stand, take measures to strengthen the motive force of ideological and political teachers teaching innovation to promote the reform of ideological and political education in colleges and universities.

\section{Acknowledgement}

In this paper, the research was sponsored by the Jilin Education Science 13th Five-Year Plan Special Project on Ideological and Political research in Colleges and Universities (Project No. GS17126).

\section{References}

[1] JIA Hongguo. Study on the reform of ideological and political teaching in colleges and universities under the background of cultural diversity[J]. Education for Chinese After-school (Theory), 2012(06).

[2] WANG Ailan, CHANG Baohong. Thoughts and suggestions on promoting the popularization of Marxism in colleges and universities[J]. Youth Years, 2011(16).

[3] SHEN Xiaohui. Brief analysis of the Reform of ideological and political education in colleges and universities[J]. Science and Technology, 2015(9).

[4] JIA Hongguo. An analysis of the reform of ideological and political teaching under the multicultural background[J]. Education for Chinese After-school(Theory),2013(9).

[5] ZHU Yuwei. Criticism and reference: an analysis of the reform of ideological and political courses in colleges and universities under the trend of pluralistic Social thought[J]. Tribune of Education Culture, 2013, 5(4):86-89.

[6] JIA Hongguo. Study on the reform of ideological and political teaching in colleges and universities under the background of cultural diversity[J]. Education for Chinese, 2010(12):31. 